Original research article

\title{
How students understand spirituality and spiritual care: Descriptive study on a sample of bachelor nursing students from Slovenia
}

\author{
Igor Karnjuš ${ }^{1}$, Jelena Bašić ${ }^{2}$, Katarina Babnik ${ }^{3}$ * \\ ${ }^{1}$ University of Primorska, Faculty of Health Sciences, Department of Nursing, Izola, Slovenia \\ 2 Clinical Hospital Center Split, Department of Gynecology and Obstetrics, Split, Croatia \\ ${ }^{3}$ University of Ljubljana, Faculty of Arts, Department of Psychology, Ljubljana, Slovenia
}

\begin{abstract}
Research shows the potential role of a specific cultural environment in understanding spirituality and spiritual care among nursing staff and students. In Slovenia, spiritual care within the framework of nursing is still under development alongside efforts for the greater professionalisation of nursing. The objectives of the study performed on a sample of nursing students from Slovenia were to: (1) explore nursing students' perceptions of spirituality and spiritual care; (2) examine the role of demographic characteristics, and (3) determine the perceived importance of education in the field of spiritual care. A quantitative, non-experimental survey research method was applied. Undergraduate nursing students enrolled in one of the Slovenian faculties participated in the study. The original Spirituality and Spiritual Rating Scale was utilised as the research instrument. Descriptive statistics were calculated for each item of the instrument and statistical tests were used to identify significant differences between the demographic characteristics of the sample and students' perceptions of and experiences with spirituality and spiritual care. The results were compared with those of previous studies on samples of nursing care students and employed nurses. The results showed that students had a pronounced existential view of spirituality and expressed doubt as to whether spiritual care should be an integral part of nursing and nursing education. Self-reported religiosity, religious practice, and gender, showed an important contribution to spirituality and spiritual care perceptions. Further multinational research on spirituality and spiritual care are needed to achieve better cultural self-awareness and development of coordinated educational programs.
\end{abstract}

Keywords: Nursing education; Nursing students; Slovenia; Spiritual care; Spirituality

\section{Introduction}

The concept of spirituality is frequently a subject of scientific debates (Timmins and McSherry, 2012) and "sceptical criticism" (Swinton and Pattison, 2010, p. 226). Numerous definitions and explanations of spirituality, from the various scientific perspectives, schools, and disciplines, and individual preferences of the authors, have created an image of spirituality as a phogiston. In the social sciences the same comparison was made by Kopelman et al. (1990, p. 287) for the concept of culture. Today, spirituality has become an important area of research in nursing and other health-related disciplines (Timmins and McSherry, 2012), with the biopsychosocial-spiritual model integrating the spiritual dimension of human beings within health care (Elias et al., 2015). Undoubtedly, an understanding of the concepts of spirituality and spiritual care depends on the prevalence and clarity of the accessible literature in this field (Timmins et al., 2015). An important factor determining the role of spirituality in spiritual care is also the wider context in which nursing education and nursing care is taking place. The aim of the study was to explore spirituality and spiritual care perceptions among nursing care students from Slovenia.

In the nursing literature, three concepts related to the term "spiritual" appear: (i) spirituality; (ii) spiritual needs and (iii) spiritual care. Since ancient times, spirituality has been linked to the concept of a good life (Ho and Ho, 2007), and in humanistic psychology to the ideal of a fully functioning person (Proctor et al., 2016). Spirituality underlies existential concerns of meaning and purpose in life, and pertains to the realm of supraordinate values (Ho and Ho, 2007). It is an "inner resource" (Van Dierendonck and Mohan, 2006, p. 234) guiding people in search of significance and strength, which becomes especially salient when facing crises and uncertainties in life (Van Dierendonck and Mohan, 2006). Illness, per se, triggers questions related to life and its meaning, such as: "Why is this happening to me?" or "Why is God allowing this suffering?" (Westera, 2017, p. 41). Parallel with the definition of spirituality, the question of the relationship between spirit-

\footnotetext{
* Author for correspondence: Katarina Babnik, University of Ljubljana, Faculty of Arts, Department of Psychology, Aškerčeva 2, 1000 Ljubljana, Slovenia; e-mail: katarina.babnik@ff.uni-lj.si http://doi.org/10.32725/kont.2019.044 
uality and religion appears. The answer is often found in the explanation of religion and spirituality as connected, integrated, but not synonymous terms (Van Dierendonck and Mohan, 2006). In a healthcare context there are practical reasons why a clear demarcation of spirituality and religion is needed; to help nurses and other professionals to recognise and observe spirituality in individuals who are not (self-defined) as religious (Pesut, 2008).

Spiritual needs can be understood as qualities that people "require or want to find purpose and meaning in life" (Monod et al., 2011, p. 1346). Westera (2017) summarises the spiritual needs that nurses might recognise in patients during nursing care as follows: a need for meaning and purpose, for love, connection and harmonious relations; for giving and receiving forgiveness; for hope and strength; for religious practices, rituals and being connected with God or a higher power; for beauty and creativity, the need for trust and preparation for death. As found by Büssing et al. (2018), spiritual needs are present in different groups of people (the healthy and sick, all ages and genders), but with different given importance, and are relevant and valid constructs for understanding an individual's endeavour to achieve spiritual well-being. Spiritual needs are also the starting point of spiritual care.

The consideration of the spiritual dimension of a patient's being is recognised by the nursing code of ethics (Ross et al., 2014), spiritual assessment tools (Timmins and Caldeira, 2017) and through the development of spirituality-related nursing interventions (Caldeira and Timmins, 2017). Although today spiritual care is recognised as a component of holistic care, more specific directions for such care in practice are still lacking (Timmins et al., 2015). Efforts to improve the situation are taking place in various European countries (Ross et al., 2014), including research activities for understanding the development of spiritual care competency among students. A multinational European study of nursing students' perceptions of spirituality, spiritual care and spiritual competency has been taking place since 2010 (Ross et al., 2014; 2018). The results of the first study (Ross et al., 2014) performed on a sample of undergraduate students show that the participants have a broad view of spirituality that includes existential and religious dimensions, and that they perceived spiritual care as an important element of nursing and midwifery. The subsequent study (Ross et al., 2018) confirmed that the students' perceptions of spiritual care competency increased over the educational process, and identified factors with the most important role in students' spiritual care competency.

At the beginning of the paper we compared the concepts of spirituality and culture. Both are interrelated through the individual beliefs, values and moral systems (Riklikiene et al., 2016) developed in the process of cultural socialisation. Studies (Riklikiene et al., 2016; Yllmaz and Gurler, 2014) indicate the possible role of specific national cultural features on the perception and practices of spirituality in the nursing educational process. Slovenia is a small European Union country with dominant eastern European cultural characteristics (Bakacsi et al., 2002). In Slovenia, nursing education is performed at the level of secondary and higher education programmes (Skela-Savič, 2017). Professionalism in nursing is still in the process of development in Slovenia, with a "lack of support within and outside the profession to increase professionalism" (Skela-Savič, 2016, p.5), and therefore it is strongly influenced by the perceptions of the nursing profession from within the occupational group itself (Skela-Savič, 2017).

The objectives of the current study were to (1) explore how Slovenian nursing students perceive the concepts of spiritual- ity and spiritual care; (2) examine the relationship between nursing students' demographic characteristics and their understanding of spirituality and spiritual care; and (3) determine how important education and training in the fields of spirituality and spiritual care is for nursing students and their nursing practice.

\section{Materials and methods}

\section{Design}

A descriptive, cross-sectional design was used.

\section{Participants}

Convenience sampling was used. All undergraduate nursing students enrolled in a Slovenian educational institution were included in the study $(n=392)$. A questionnaire was administered to bachelor nursing students from the first, second and third years. A response rate of $73.98 \%(n=290)$ was achieved.

\section{Instrument}

A questionnaire developed by McSherry (McSherry, 1998; McSherry et al., 2002) was used. The questionnaire was structured in four parts: i) Spirituality and Spiritual Care Rating Scale (SSCRS), ii) Questions about nursing practice, iii) The role of educational institutions and regulatory bodies, and vi) Demographics. The rationale for using SSCRS is that it has already been used in several studies that draw their samples from nursing students (McSherry et al., 2008; Ross et al., 2014; 2018). The SSCRS includes 17 statements scored on a 5-point Likert scale (ranging from 1-strongly disagree to 5-strongly agree). It explores four main factors (Ross et al., 2014): Factor I - Existential Spirituality (items F, H, I, J, L); Factor II - Spiritual Care (A, B, G, K, N); Factor III - Religiosity (D, M, P); Factor IV - Personal Care (N, O, Q). The SSCRS has demonstrated consistent levels of validity (Fallahi-Khosknab et al., 2010; McSherry, 1998). Written consent for the use of SSCRS was obtained from the author of the original version. The linguistic and cultural equivalence of the SSCRS for the Slovenian population was achieved through translation and back-translation by the authors of the study and a professional bilingual translator. Items were adapted to the current policy of healthcare in Slovenia in those pertaining to the third part of the questionnaire (on the role of educational institutions and regulatory bodies). The results of the reliability analysis of the SSCRS scale showed its satisfactory internal consistency (Cronbach's alpha coefficient $=0.714$ ). The Slovenian version of the instrument was utilised also on a sample of Slovenian nurses employed in clinical settings (Montanič Starc et al., 2019).

\section{Data collection procedure}

Permission to conduct the study at the undergraduate nursing program was obtained from the Dean of the Faculty. The participants were given verbal and written information about the study. Participation in the study was voluntary. The confidentiality and anonymity of the participants were assured and maintained during the completion and submission of the questionnaire.

\section{Data analysis}

Descriptive statistical tests were used (frequencies, percentages, mean values, standard deviations, modes). T-test and ANOVA were used to test differences in the samples' average 
total SSCRS scores in relation to demographic characteristics. Chi-square and Mann-Whitney $U$ tests were used to identify any significant differences between the demographic characteristics of the sample and students' experiences with spiritual care in the clinical settings, and their perceptions about the importance of education and training in this field. The statistical significance was set at $p<0.05$. The interpretation of the descriptive statistical data was based on the criterion used by Ross et al. (2018) (scores +/- >3.5). Statistical analyses were carried out using the statistical program SPSS version 23.0 (SPSS Inc., Chicago, Illinois, USA).

\section{Results}

\section{Demographic profile of the respondents}

From a total of 290 respondents, 221 (76.2\%) were female and $69(23.8 \%)$ were male; their mean age was 22.39 years $(S D=$ 5.01 , median $=21$, range 19-48). A more detailed distribution by years of the study is shown in Table 1 .

Table 1. Distribution of the participants by year of nursing care study programme $(n=290)$

\begin{tabular}{lc} 
Year of the study & $\%(n)$ \\
\hline First year & $39.0 \%(113)$ \\
Second year & $31.0 \%(90)$ \\
Third year & $30.0 \%(87)$ \\
Total & $100.0 \%(290)$ \\
\hline & \\
participating in the study & \\
\hline
\end{tabular}

The majority of the respondents were of Slovenian nationality (203; 70.0\%). The respondents were also asked about their religion. Christianity was the most frequently self-identified religion (209; 72.1\%), while 64 of the respondents $(22.1 \%)$ indicated that they were not religious. Of those respondents who identified as religious (226; 77.9\%), 152 (67.3\%) stated that they practised their religion.

\section{Responses on the Spirituality and Spiritual Rating Scale}

The overall scores of SSCRS are presented in Table 2 in the form of mean values, $S D$, modes and range of responses. The range of responses for SSCRS was fairly wide (1-5 for all statements). The mean SSCRS score for respondents $(n=290)$ was 3.45 ( $S D=0.87$ ) (per item). The sample tended towards an existential view of spirituality (that spirituality is concerned with peoples' sense of meaning, purpose, value, peace and creativity) (mean $=3.66 ; S D=0.91$ ) and less so towards one that included only religious beliefs and practices (mean $=2.26$; $S D=0.95)$. In fact, the vast majority of the respondents strongly disagreed (36.9\%) or disagreed (47.9\%) with the statement that "spirituality only involves going to a church/place of worship". Students considered both spiritual care (in its broadest sense, including religious and existential elements) (mean = 4.07; $S D=0.77$ ) and personal care (taking into account peoples' beliefs and values and dignity) (mean $=3.84 ; S D=0.82$ ) as being important.

There were no significant differences in terms of the average total SSCRS and the year of study $(F=2.918, p=0.056)$.
However, there was a difference in the SSCRS score for students who identified as religious or not, and for those who were practising their religion or not. The mean SSCRS score for students who declared themselves as religious was 3.50 $(S D=0.36)$ compared to $3.32(S D=0.38 ; t=3.360, p=0.001)$ for those who said they were nonreligious. Students who practiced their religion had a higher SSCRS mean score (mean $=$ $3.55, S D=0.33$ ) compared to those who did not (mean $=3.35$, $S D=0.39 ; t=4.565, p=0.000)$. Furthermore, there was a significant difference in terms of the SSCRS score and the gender, where the mean SSCRS score of the female students was higher (mean $=3.48, S D=0.35$ ) than that of the male students (mean $=3.38, S D=0.42 ; t=-1.795, p=0.049$ ).

\section{Spiritual care in clinical settings}

In this part we explored students' experiences with spiritual care in clinical settings. Approximately half of the respondents $(50.3 \%)$ stated that during the course of their clinical practice they had encountered patients with spiritual needs. A greater proportion of the senior students (third year of the study programme) had encountered patients with spiritual needs $(65.1 \%)$ compared with those in the first year $(42.3 \%)$ $\left(\chi^{2}=9,916, p=0.007\right)$. Students who stated that they practised their religion perceived the spiritual needs of patients to a greater extent (32.6\%) compared to students who did not practice it $(19.1 \%)\left(\chi^{2}=4.895, p=0.036\right)$. The most frequent modes of recognising the spiritual needs of patients in a clinical setting were as follows: recognised by patient himself/ herself $(n=130)$, by listening to and observing the patient $(n=103)$ and from the patient's relatives/friends $(n=77)$. The majority of respondents stated that they encountered patients with spiritual needs on a yearly (27.1\%), monthly (25.7\%), weekly $(24.3 \%)$ or daily basis $(20.4 \%)$. The majority of respondents (84.5\%) felt they were only able to sometimes meet the patient's spiritual needs, with $12.1 \%$ stating "always" and $3.4 \%$ stating "never". However, the majority of the respondents did not feel that nurses alone are responsible for delivering spiritual care. Of the students sampled, 127 (43.8\%) felt that nurses, chaplains, patients, family and friends and other healthcare professionals were also responsible for providing spiritual care.

The students were also asked to identify from a list of eight needs those that were in their opinion spiritual needs (Table 3 ). The need for forgiveness and the need for a source of hope and strength were most frequently selected as spiritual needs. Students who identified themselves as religious $(n=226)$ and those who stated that they practised their religion $(n=152)$ put more stress on the need for spiritual practices, expressions of belief in the concept of God or a deity $\left(\chi^{2}=6.612, p=0.012\right)$ and the need for forgiveness $\left(\chi^{2}=4.698, p=0.033\right)$ in comparison with other students. Moreover, female students more often chose the need for an expression of personal beliefs/values than male students (Mann-Whitney $U=6426.0, p=0.038$ ).

\section{The role of educational institutions and regulatory bodies}

The overall scores indicate that students are rather hesitant (mode $=3$ ) about the importance of spirituality and spiritual care in the nursing profession (statement 1 and statement 6), although the majority (53.5\%) "disagreed" or "strongly disagreed" that spirituality and spiritual care should not be addressed within programmes of nurse education (statement 3). The overall results of this part of the questionnaire are presented in Table 4. 
Table 2. Summary of responses to the SSCRS $(n=290)$

\begin{tabular}{|c|c|c|c|c|c|}
\hline & Statement & Range & Mean & $S D$ & Mode \\
\hline A & $\begin{array}{l}\text { I believe nurses can provide spiritual care by arranging a visit by the hospital } \\
\text { chaplain or the patient's own religious leader if requested }\end{array}$ & $1-5$ & 4.13 & 0.73 & 4 \\
\hline $\mathrm{B}$ & $\begin{array}{l}\text { I believe nurses can provide spiritual care by showing kindness, concern and } \\
\text { cheerfulness when giving care }\end{array}$ & $1-5$ & 4.17 & 0.76 & 4 \\
\hline C & I believe spirituality is concerned with a need to forgive and a need to be forgiven & $1-5$ & 3.77 & 0.86 & 4 \\
\hline $\mathrm{D}$ & I believe spirituality only involves going to church/place of worship & $1-5$ & 1.84 & 0.82 & 2 \\
\hline $\mathrm{E}$ & $\begin{array}{l}\text { I believe spirituality is not concerned with a belief and faith in God or a Supreme } \\
\text { being }\end{array}$ & $1-5$ & 3.79 & 1.05 & 4 \\
\hline $\mathrm{F}$ & I believe spirituality is about finding meaning in the good and bad events of life & $1-5$ & 3.74 & 0.92 & 4 \\
\hline G & $\begin{array}{l}\text { I believe nurses can provide spiritual care by spending time with a patient, giving } \\
\text { support and reassurance especially in times of need }\end{array}$ & $1-5$ & 3.95 & 0.80 & 4 \\
\hline $\mathrm{H}$ & $\begin{array}{l}\text { I believe nurses can provide spiritual care by enabling a patient to find meaning and } \\
\text { purpose in their illness }\end{array}$ & $1-5$ & 3.36 & 0.96 & 4 \\
\hline I & I believe spirituality is about having a sense of hope in life & $1-5$ & 3.82 & 0.87 & 4 \\
\hline $\mathrm{J}$ & I believe spirituality is to do with the way one conducts one's life here and now & $1-5$ & 3.47 & 0.96 & 4 \\
\hline $\mathrm{K}$ & $\begin{array}{l}\text { I believe nurses can provide spiritual care by listening to patients and giving them } \\
\text { time to discuss and explore their fears, anxieties and troubles }\end{array}$ & $1-5$ & 3.96 & 0.76 & 4 \\
\hline $\mathrm{L}$ & $\begin{array}{l}\text { I believe spirituality is a unifying force which enables one to be at peace with oneself } \\
\text { and the world }\end{array}$ & $1-5$ & 3.91 & 0.82 & 4 \\
\hline M & I believe spirituality does not include areas such as art, creativity and self-expression & $1-5$ & 2.52 & 1.01 & 2 \\
\hline $\mathrm{N}$ & $\begin{array}{l}\text { I believe nurses can provide spiritual care by having respect for the privacy, dignity } \\
\text { and religious and cultural beliefs of a patient }\end{array}$ & $1-5$ & 4.17 & 0.79 & 4 \\
\hline $\mathrm{O}$ & I believe spirituality involves personal friendships and relationships & $1-5$ & 3.51 & 0.92 & 4 \\
\hline $\mathrm{P}$ & I believe spirituality does not apply to atheists or agnostics & $1-5$ & 2.43 & 1.02 & 2 \\
\hline Q & I believe spirituality includes peoples' morals & $1-5$ & 3.84 & 0.76 & 4 \\
\hline
\end{tabular}

\section{Table 3. Spiritual needs: frequency of selection}

\begin{tabular}{lcc}
\hline Items & $n$ & $\%$ \\
\hline The need for forgiveness & 220 & 75.9 \\
The need for a source of hope and strength & 215 & 74.1 \\
The need for spiritual practices, expressions of belief in the concept of God or a deity & 199 & 177 \\
The need for an expression of personal beliefs/values & 161 & 146.6 \\
The need for trust & 141 & 55.5 \\
The need for love and harmonious relationships & 62 & 48.6 \\
The need for meaning and purpose & 21.4 \\
The need for creativity & \\
\hline$n$ - number of selections; $\%$ - percentage of all selections &
\end{tabular}

Statistically significant differences in the responses to this part of the questionnaire were related to two demographic variables - gender and practicing religion or not. Female students (36.2\%) "disagreed" to a greater extent than male students (8.4\%) with the statement that spirituality and spiritual care should not be addressed within programmes of nurse education (Mann-Whitney $U=6217.5, p=0.029$ ). Furthermore, female students more favourably evaluated the statement that spirituality and spiritual care are fundamental aspects of nursing (Mann-Whitney $U=6219.0, p=0.031$ ).
Students who stated that they practised their religion also felt more strongly that there is a need for the Ministry of Health $\left(\chi^{2}=14.220, p=0.007\right)$ and Nurses and Midwives Association $\left(\chi^{2}=14.055, p=0.007\right)$ to provide clear guidance and support for nurses regarding spirituality and spiritual care. However, students who did not practice their religion expressed more support for the idea that nurses receive sufficient education and training in order to provide quality spiritual care $\left(\chi^{2}=\right.$ $11.485, p=0.022$ ). 
Table 4. Summary of responses regarding the role of educational institutions and regulatory bodies in the field of spirituality and spiritual care in nursing $(n=290)$

\begin{tabular}{|c|c|c|c|c|}
\hline Items & Range & Mean & $S D$ & Mode \\
\hline I believe that spirituality and spiritual care are fundamental aspects of nursing & $1-5$ & 2.94 & 0.92 & 3 \\
\hline $\begin{array}{l}\text { I believe that nurses do not receive sufficient education and training in order to } \\
\text { provide quality spiritual care to the patient }\end{array}$ & $1-5$ & 3.32 & 1.03 & 4 \\
\hline $\begin{array}{l}\text { I believe that spirituality and spiritual care should not be addressed within } \\
\text { programmes of nurse education }\end{array}$ & $1-5$ & 2.62 & 0.99 & 2 \\
\hline $\begin{array}{l}\text { I believe that the Ministry of Health should provide clear guidance and support } \\
\text { for nurses to deal with spiritual and religious issues }\end{array}$ & $1-5$ & 3.43 & 0.91 & 4 \\
\hline $\begin{array}{l}\text { I believe that Nurses and Midwives Association of Slovenia should provide clear } \\
\text { guidance and support for nurses to deal with spiritual and religious issues }\end{array}$ & $1-5$ & 3.51 & 0.87 & 4 \\
\hline $\begin{array}{l}\text { I believe that spiritual care should be an integral part of nursing lifelong } \\
\text { education and mandatory content for the renewal of licenses }\end{array}$ & $1-5$ & 2.81 & 1.01 & 3 \\
\hline
\end{tabular}

\section{Discussion}

The results of the study will be interpreted in accordance with the structure of the questionnaire used to collect the data.

\section{Perceptions of spirituality and spiritual care (SSCRS)}

An examination of the average scores on items describing the existential and religious dimensions of the definition of spirituality shows that the students stressed the existential dimension over the religious one. The average score for the dimension of Existential Spirituality found within our sample is similar to that found in the first and second waves of Ross et al. (2018), but the average score on the Religiosity dimension was substantially lower in the current work. The overall mean score on the SSCRS was much lower compared to that found in $\mathrm{Wu}$ et al. (2012), especially due to the lower level of agreement for the items defining the Religiosity and Existential Spirituality dimensions in our sample. The nursing students from Slovenia were more reserved in their evaluation of spirituality compared to previous international studies performed on nursing care students (Ross et al., 2018; Wu et al., 2012), although similar to a sample of already employed nurses from Slovenia (Montanič Starc et al., 2019). Their evaluations suggest the greater importance of a horizontal view of spirituality (Noormohammadi et al., 2018), and a rather secular attitude towards spirituality. These results might be due to students' understanding of nursing care, acquired in a specific socio-cultural environment, with historically a predominantly secular tradition (Smrke and Uhan, 2012). On the other hand, a pronounced non-religious perspective on spirituality might be related to a poorer understanding of spirituality and its relation to religion (Daghan, 2018). Similar to previous studies, the current work also found that perceptions of spirituality and spiritual care differ with regard to individuals' self-reported religiosity and religious practice (Cockell and McSherry, 2012; Montanič Starc et al., 2019), as well as gender (Daghan, 2018; Wu et al., 2012).

\section{Spiritual care in clinical settings}

The sample of Slovenian nursing students examined in this work reported that they had already encountered the spiritual needs of patients. Students with more experience in a clinical environment - i.e., in the third year of study - more often reported having encountered patients' spiritual needs than those enrolled in the first, although their overall perceptions of spirituality, as indicated by the average score on the SSCRS, did not differ substantially. Students that identified themselves as practicing their religion were more likely to report that they have encountered the spiritual needs of patients than those who stated they did not practice a religion. A nurse's attitude towards spirituality and religion has a strong influence on how much attention he or she will devote to this aspect of care for a patient in a clinical setting (Narayanasamy and Owens, 2001).

McSherry and Jamieson (2011) found that nurses identify patients' spiritual needs through their interactions with patients, their relatives and friends, and through listening and observing. The current study also found the same most common approaches to the identification of patients' spiritual needs in the sample of Slovenian nursing students. The students identified the three most characteristic spiritual needs as follows: (i) the need for forgiveness, (ii) the need for a source of hope and strength, and (iii) the need for spiritual practices, such as expressions of belief in the concept of God or a deity. The least frequently identified spiritual needs were: (i) the need for creativity, (ii) the need for meaning and purpose and (iii) the need for love and harmonious relationships. Similarly, McSherry and Jamieson (2011) found creativity to be the characteristic least frequently identified as a spiritual need, although creativity is per se an expression of meaning and a vehicle for communicating meaning (McSherry, 2006). Although the current sample of students from Slovenia evaluated the concept of spirituality primarily through an existentialist lens, they more frequently identified "the need for spiritual practices, expressions of belief in the concept of God or a deity" than they did for "the need for meaning and purpose".

\section{The role of educational institutions and regulatory bodies}

The analysis of students' answers to the third part of the questionnaire showed some uncertainty about the importance of spirituality and spiritual care in the nursing profession. More specifically, the respondents' expressed doubts as to whether spiritual care should be an integral part of nursing and of optional and mandatory nursing lifelong education. A very similar pattern of perceptions about the role of spirituality in nursing care and its inclusion into various forms of nursing education to that found in the current study of nursing 
students was also reported based on a sample of already employed nurses from Slovenia (Montanič Starc et al., 2019). The doubts about the importance of spirituality and spiritual care are probably due to the various interrelated factors that determine students' knowledge of and attitudes towards spirituality. Although the main limitation of our study is its small sample, taken only from one faculty that educates future nurses, the results should also be interpreted from a broader, cultural perspective. The cultural environment in which nursing care and education take place in Slovenia sees the fulfilment of a patient's physiological needs as the primary role of nurses (Babnik et al., 2017). Such expectations reflect the predominant biomedical model of the concept of health and disease (Babnik et al., 2017), in which the psycho-social-spiritual dimensions of being are less pronounced. Social representations are also shaped by nursing professionals themselves, and are passed on to nursing care students through role-modelling during clinical practice. Slovenia is committed to following the European Directive (Directive 2013/55/EU of the European Parliament and of the Council, 2013; Skela-Savič, 2017), but this framework cannot be sufficient to change social representations and guarantee more uniform perceptions about the nursing profession in various cultural environments within the European Union. The importance of the spiritual dimension of one's individual being is addressed by the code of ethics (Nurses and Midwives Association of Slovenia, 2005). Nursing education and practice would benefit from more specific guidelines to provide spiritual care (Timmins et al., 2015), but at the same time, further multinational studies on spirituality and spiritual care are needed to provide knowledge for improvement of cultural self-awareness in relation to the spiritual dimension of an individual's being.

\section{Conclusions}

Students showed a pronounced existential perspective towards spirituality in nursing care, although they also recognised religious practices and guidance as an important spiritual need. Uncertainty and doubt about the importance of spirituality and spiritual care was also detected in the sample of nursing students. Individual characteristics, especially self-reported religiosity, practicing religiosity and gender, had important impacts on spirituality and spiritual care perceptions. Current international research endeavours on the perceptions of spirituality and spiritual care in nursing students offer an important contribution to the understanding of the role of nursing care role in spirituality, and for the development of educational contents and approaches for both study and lifelong learning in nursing care.

\section{Conflict of interests}

The authors confirm that they have no conflicts of interest associated with this publication. The authors confirm that this research did not receive any specific grant from funding agencies in the public, commercial, or not-for-profit sectors.

\title{
Jak studenti chápou spiritualitu a duchovní péči: Deskriptivní studie studentů bakalářského oboru ošetřovatelství ve Slovinsku
}

\begin{abstract}
Souhrn
Výzkum poukazuje na potencionální roli specifického kulturního prostředí, které hraje roli při porozumění spirituality a duchovní péče mezi ošetřujícím personálem a studenty. Duchovní péče se ve Slovinsku stále vyvíjí a zvyšuje se i úsilí o větší profesionalitu ošetřovatelského personálu. Cíle studie, která byla provedena na vzorku studentů ošetřovatelství ze Slovinska, byly: (1) prozkoumat, jak studenti ošetřovatelství vnímají spiritualitu a duchovní péči; (2) prozkoumat roli demografických charakteristik; (3) zjistit, jaká důležitost je přikládána vzdělání v oblasti duchovní péče. Aplikovány byly kvantitativní a analytické metody výzkumu. Studie se zúčastnili studenti bakalářského oboru ošetřovatelství na jedné slovinské fakultě. Pro hodnocení chápání spirituality a duchovní péče byla použita měřicí škála. Pro každou položku byla vypracována popisná statistika a pro zjištění významných rozdílů mezi demografickými charakteristikami a vnímáním spirituality a duchovní péče studenty byly použity statistické testy. Výsledky byly porovnány s výsledky předchozích studií, které byly provedeny na vzorku studentů ošetřovatelství a na zdravotních sestrách. Výsledky ukázaly, že studenti měli výrazný existenční pohled na spiritualitu a vyjádřili pochybnosti o tom, zda by duchovní péče měla být součástí ošetřovatelského vzdělávání. Vlastní víra, náboženská praxe a pohlaví výrazně ovlivňovaly přístup ke spiritualitě a duchovní péči. K dosažení lepšího kulturního sebeuvědomění a rozvoji koordinovaných vzdělávacích programů je třeba provést další, nadnárodní výzkum týkající se spirituality a duchovní péče.
\end{abstract}

Klíčová slova: duchovní péče; ošetřovatelství; Slovinsko; spiritualita; studenti; vzdělávání v ošetřovatelství

\section{References}

1. Babnik K, Hvalič Touzery S, Pesjak K, Skela-Savič B (2017). Zdravstvena nega kot stroka in znanost: pogled osnovnošolcev, dijakov in študentov zdravstvene nege [Nursing as a profession and science: views of primary school pupils, nursing high school students and students of bachelor nursing care study programmes]. In: Skela-Savič B, Hvalič Touzery S (Eds). Continuous development of nursing in society and its contribution to health promotion: Proceedings of lectures with peer review: 10th International Scientific Conference, 8th and 9th June 2017, Bled, Slovenia. Jesenice: Angela Boškin Faculty of Health Care, pp.74-82.
2. Bakacsi G, Sándor T, András K, Viktor I (2002). Eastern European cluster: tradition and transition. Journal of World Business 37(1): 69-80. DOI: 10.1016/S1090-9516(01) 00075-X.

3. Büssing A, Recchia DR, Koenig H, Baumann K, Frick E. (2018). Factor structure of the Spiritual Needs Questionnaire (SPNQ) in persons with chronic diseases, elderly and healthy individuals. Religions 9(1): 13. DOI: 10.3390/rel9010013.

4. Caldeira S, Timmins F (2017). Implementing spiritual care interventions. Nurs Stand 31(34): 54-60. DOI: 10.7748/ ns.2017.e10313.

5. Cockell N, McSherry W (2012). Spiritual care in nursing: an overview of published international research. J Nurs Manag 20(8): 958-969. DOI: 10.1111/j.1365-2834.2012.01450.x. 
6. Daghan S (2018). Nursing students' perceptions of spirituality and spiritual care; an example of Turkey. J Relig Health 57(1): 420-430. DOI: 10.1007/s10943-017-0416-y.

7. Directive 2013/55/EU of the European Parliament and of the Council (2013). Official Journal of the European Union, L354/132. [online] [cit. 2019-01-04]. Available from: https://eur-lex.europa.eu/LexUriServ/LexUriServ. do?uri=OJ:L:2013:354:0132:0170:en:PDF

8. Elias AC, Ricci MD, Rodriguez LH, Pinto SD, Giglio JS, Baracat EC (2015). The biopsychosocial spiritual model applied to the treatment of women with breast cancer, through RIME intervention (relaxation, mental images, spirituality). Complement Ther Clin Pract 21(1): 1-6. DOI: 10.1016/j. ctcp.2015.01.007.

9. Fallahi-Khoshknab M, Mazaheri M, Maddah SS, Rahgozar M (2010). Validation and reliability test of Persian version of The Spirituality and Spiritual Care Rating Scale (SSCRS). J Clin Nurs 19(19-20): 2939-2941. DOI: 10.1111/j.13652702.2010.03411.x.

10. Ho DY, Ho RT (2007). Measuring spirituality and spiritual emptiness: Toward ecumenicity and transcultural applicability. Rev Gen Psycho 11(1): 62-74. DOI: 10.1037/10892680.11.1.62

11. Kopelman RE, Brief AP, Guzzo RA (1990). The role of climate and culture in productivity. In: Schneider B (Ed.) Organizational climate and culture. San Francisco: Jossey-Bass, pp. 282-318.

12. McSherry W (1998). Nurses' perceptions of spirituality and spiritual care. Nurs Stand 13(4): 36-40. DOI: 10.7748/ ns1998.10.13.4.36.c2537.

13. McSherry W (2006). Making sense of spirituality in nursing and health care practice: An interactive approach. Jessica Kingsley Publishers.

14. McSherry W, Jamieson S (2011). An online survey of nurses' perceptions of spirituality and spiritual care. J Clin Nurs 20(1112): 1757-1767. DOI: 10.1111/j.1365-2702.2010.03547.x.

15. McSherry W, Draper P, Kendrick D (2002). The construct validity of a rating scale designed to assess spirituality and spiritual care. Int J Nurs Stud 39(7): 723-734. DOI: 10.1016/ S0020-7489(02)00014-7.

16. McSherry W, Gretton M, Draper P, Watson R (2008). The ethical basis of teaching spirituality and spiritual care: A survey of student nurses perceptions. Nurse Educ Today 28(8): 1002 1008. DOI: 10.1016/j.nedt.2008.05.013.

17. Monod S, Brennan M, Rochat E, Martin E, Rochat S, Büla CJ (2011). Instruments measuring spirituality in clinical research: a systematic review. J Gen Intern Med 26(11): 1345-1357. DOI: 10.1007/s11606-011-1769-7.

18. Montanič Starc T, Karnjuš I, Babnik K (2019). Attitudes towards spirituality and spiritual care among employees in nursing care employed in hospitals. Obzornik zdravstvene nege 53(1): 31-48. DOI: 10.14528/snr.2019.53.1.313.

19. Narayanasamy A, Owens J (2001). A critical incident study of nurses' responses to the spiritual needs of their patients. J Adv Nurs 33(4): 446-455. DOI: 10.1046/j.13652648.2001.01690.x.

20. Noormohammadi MR, Etemadifar S, Rabiei L, Deris F, Jivad N, Masoudi R (2018). Identification of concepts of spiritual care in Iranian peoples with multiple sclerosis: A qualitative study. J Relig Health 58(3): 949-964. DOI: 10.1007/s10943-0170549-z.
21. Nurses and Midwives Association of Slovenia (2005). The code of ethics for nurses and nurse assistants of Slovenia. Ljubljana: Nurses and Midwives Association of Slovenia. [online] [cit. 2019-01-07]. Available from: https://www.zbornica-zveza.si/ sites/default/files/doc_attachments/code_of_ethics_0.pdf

22. Pesut B (2008). Spirituality and spiritual care in nursing fundamentals textbooks. J Nurs Educ 47(4): 167-173.

23. Proctor C, Tweed R, Morris D (2016). The Rogerian fully functioning person: A positive psychology perspective. J Humanist Psychol 56(5): 503-529. DOI: $10.1177 / 0022167815605936$.

24. Riklikiene O, Vozgirdiene I, Karosas LM, Lazenby M (2016). Spiritual care as perceived by Lithuanian student nurses and nurse educators: A national survey. Nurse Educ Today 36: 207-213. DOI: 10.1016/j.nedt.2015.10.018.

25. Ross L, McSherry W, Giske T, van Leeuwen R, SchepAkkerman A, Koslander T, Hall J, et al. (2018). Nursing and midwifery students' perceptions of spirituality, spiritual care, and spiritual care competency: A prospective, longitudinal, correlational European study. Nurse Educ Today 67: 64-71. DOI: 10.1016/j.nedt.2018.05.002.

26. Ross L, Van Leeuwen R, Baldacchino D, Giske T, McSherry W, Narayanasamy A, Downes C, et al. (2014). Student nurses perceptions of spirituality and competence in delivering spiritual care: a European pilot study. Nurse Educ Today 34(5): 697-702. DOI: 10.1016/j.nedt.2013.09.014.

27. Skela-Savič B (2016). Professionalism in nursing: what is its current level in Slovenia? Obzornik zdravstvene nege 50(1): 4-9. DOI: 10.14528/snr.2016.50.1.94.

28. Skela-Savič B (2017). Professionalization of nursing in Slovenia: challenges and responsibilities for nurses with a higher education degree. Obzornik zdravstvene nege 51(4): 264-273. DOI: 10.14528/snr.2017.51.4.202.

29. Smrke M, Uhan S (2012). Atheism in post-socialist conditions: the case of Slovenia. Teorija in praksa 49(3): 46-69.

30. Swinton J, Pattison S (2010). Moving beyond clarity: Towards a thin, vague, and useful understanding of spirituality in nursing care. Nurs Philos 11(4): 226-237. DOI: 10.1111/j.1466769X.2010.00450.x.

31. Timmins F, Caldeira S (2017). Assessing the spiritual needs of patients. Nurs Stand 31(29): 47-53. DOI: 10.7748/ns.2017. e10312.

32. Timmins F, McSherry W (2012). Spirituality: the Holy Grail of contemporary nursing practice. J Nurs Manag 20(8): 951-957. DOI: $10.1111 /$ jonm.12038.

33. Timmins F, Neill F, Murphy M, Begley T, Sheaf G (2015). Spiritual care competence for contemporary nursing practice: A quantitative exploration of the guidance provided by fundamental nursing textbooks. Nurse Educ Pract 15(6): 485-491. DOI: 10.1016/j.nepr.2015.02.007.

34. Van Dierendonck D, Mohan K (2006). Some thoughts on spirituality and eudaimonic well-being. Ment Health Relig Cult 9(3): 227-238. DOI: 10.1080/13694670600615383.

35. Westera D (2017). Spirituality in Nursing Practice: The Basics and Beyond. New York: Springer Publishing Company.

36. Wu LF, Liao YC, Yeh DC (2012). Nursing student perceptions of spirituality and spiritual care. J Nurs Res 20(3): 219-227. DOI: 10.1097/jnr.0b013e318263d956.

37. Yllmaz M, Gurler H (2014). The efficacy of integrating spirituality into undergraduate nursing curricula. Nurs Ethics 21(8): 929-945. DOI: 10.1177/0969733014521096. 